\title{
PREVALENCE OF HEARING LOSS IN MILITARY AVIATORS: THE AUDIOMETRY AND RISK FACTORS ANALYSIS
}

Alam MR ${ }^{1}$, Wahab MA², Rahman $\mathrm{MM}^{3}$, Asaduzzaman $\mathrm{AKM}^{4}, \mathrm{Al}-\mathrm{Azad}$ MAS ${ }^{5}, \mathrm{Karim} \mathrm{MI}^{6}$, Sultana $\mathrm{S}^{7}$

\begin{abstract}
Introduction: Noise Induced Hearing Loss (NIHL) is an occupational health hazard linked with noise exposure of more than $85 \mathrm{~dB}$. Aircraft noise and other occupational noise exposure cause military aviators more susceptible to NIHL than commercial jet pilots.
\end{abstract}

Aim: To find out the prevalence of noise induced hearing loss among different military aircrew population with special emphasis on identifying the associated risk factors.

Materials and Methods: This cross sectional study was conducted on Kuwait Air force pilots those who came for annual medical checkup from July 2010 to July 2012. Audiometry of all subjects was done by ENT specialist and necessary data were collected by structured questionnaires. All data were analyzed by SPSS (Statistical Package for the Social Sciences) version 17.0

Results: Out of 221 aircrew 32 (14.48\%) developed NIHL. Hearing loss was mild to moderate and predominately at high frequencies. Most affected group was helicopter pilots. Pilots of more than 40 years of age and those who had more than 1000 flying hours had mean hearing threshold more than other groups. The right ear was affected in majority of cases than left ear.
Conclusion: Noise exposure to aircrew is inevitable so hearing loss prevention strategies might play a pivotal role to save aircrew hearing. Active surveillance of hearing protection practices might have beneficiary effect. Steps can be taken for early detection of NIHL and hearing conservation program.

Key-Words: Noise Induced Hearing Loss, Aircraft noise, Military aviators, Audiometry

\section{Introduction}

The steady state noise of aircraft engine is a product of civilization that is exposed to the aircrew population in their day to day life. In comparison to commercial jet pilots, the military aviators are exposed to a potentially harmful level of noise that might be a major risk factor for permanent hearing loss. The noise level as low as $74 \mathrm{~dB}$ have been shown to cause at least temporary hearing loss but permanent hearing loss depends on the level of noise, duration of exposure, individual susceptibility and use of personal hearing protection $^{1,2}$. Repeated exposure to noise in excess of $85 \mathrm{~dB}$ will cause permanent, predominately high frequency hearing loss due to damage of sensory hair cell in the basal turn of cochlea ${ }^{1,3,4}$. The hearing loss initially occurs at $4 \mathrm{kHz}$ but gradually spread to other

1. Maj Md Rabiul Alam, MBBS, D Av Med, Graded Specialist in Aero Space Medicine, BAF, Deputed to Kuwait Air Force (KAF) 2. Maj Md Abdul Wahab, MBBS, MD, Classified Specialist in Biochemistry, AFMC, Deputed to KAF. 3. Maj Md Masudur Rahman, MBBS, Graded Specialist in Aero Space Medicine, BAF, Deputed to KAF. 4. Lt Col AKM Asaduzzaman, MBBS, DLO, MCPS, FCPS, Graded Specialist in ENT, CMH, Dhaka Cantt. 5. Lt Col Md Abdus Samad Al-Azad, MBBS, MCPS, DFM, Asstt Prof, Forensic Medicine, AFMC, Dhaka Cantt. 6. Lt Col Md Iqbal Karim, MBBS, MCPS, DCP, FCPS (Histopathology), Asstt Prof of Pathology, AFMC, Dhaka Cantonment. 7. Lt Col Sharmeen Sultana, MBBS, MPhil, HOD in Physiology, AFMC, Dhaka Cantt. 
frequencies ${ }^{3,4}$. Aim of this study was to find out the prevalence of noise induced hearing loss (NIHL) among the different aircrew population. The audiometry of individual pilot was analyzed along with survey of risk factors that might be a contributory factor for hearing loss.

The occupational hearing loss assessment may be perplexed by number of factors. Here in this study a special focus was given to age, hours of exposure, type of aircraft flown, leisure noise exposure, childhood otitis media, acoustic trauma, use of hearing protection, otitis barotrauma and ototoxic medication ${ }^{5}$. At enrollment in air force all cadets were examined by audiometry and normal hearing threshold was $20 \mathrm{~dB}$ or less hearing loss at any frequency ${ }^{5}$. The magnitude of hearing loss was assessed basing on the base line data on entry to air force.

\section{Methods}

This cross sectional study was conducted from July 2010 to July 2012 in all the bases of Kuwait Air Force. Pilots who came to flight surgeon's office for annual medical examination were included in this study. All of them were instructed to refrain from acute aircraft noise exposure/any loud noise exposure before audiometry check up. The audiometry was done in ENT department by specialist in armed forces hospital. The hearing threshold were measured once at each of ten pure tone frequencies $(250,500,750,1000,2000,3000$, $4000,6000,8000 \mathrm{~Hz})$. The thresholds were determined by increasing and decreasing the sound levels of $5 \mathrm{~dB}$ to find the critical value that separates audible from inaudible range. All individuals who had hearing loss of more than 20 $\mathrm{dB}$ at any frequency were considered as NIHL positive case. Necessary data were collected from the study subjects by structured questionnaires. The questionnaires included the age, type of aircraft flown, hours of flying, any history of acoustic trauma/ barotraumas, history of head injury, use of ototoxic medication, any type of leisure noise exposure and use of hearing protection in flight. All the collected data were analyzed by computer software SPSS version 17.0. To see the statistical significance $\mathrm{X}^{2}$ test was done for qualitative data and for quantitative data' $t$ ' test and one way ANOVA test was done. $\mathrm{P}$ value $<.05$ was considered as significant.

\section{Results}

A total of 221 pilots participated in this study (Table-I). Among them 57.92\% $(\mathrm{n}=128)$ were helicopter, $30.77 \%(n=68)$ were fighter and 11.31 $\%(n=25)$ were transport pilots. Among the Helicopter pilot population $15.63 \% \quad(n=20)$ developed hearing loss where as $14.70 \%(\mathrm{n}=10)$ and $8 \%(\mathrm{n}=02)$ of fighter and transport pilot population respectively developed hearing loss. In total pilot population in this study group $14.48 \%$ $(n=32)$ developed hearing loss. Hearing loss among the different aircrew population was not statistically significant $\left(X^{2}=.984: \mathrm{df}=2: \mathrm{p}>0.05\right)$. In the helicopter pilot population the percentage of hearing loss is higher than fighter and transport pilots but the one way ANOVA test does not reveal significant $(\mathrm{p}>0.5)$ difference in hearing loss among the group(Table-I).

Table-I: Frequency Distribution of Subject by Aircraft Type $(n=221)$

\begin{tabular}{|c|c|c|c|}
\hline $\begin{array}{c}\text { Type of } \\
\text { aircraft }\end{array}$ & $\begin{array}{c}\text { Number } \\
\text { participated }\end{array}$ & $\begin{array}{c}\text { Number of } \\
\text { hearing loss }\end{array}$ & $\begin{array}{c}\% \text { of hearing } \\
\text { loss }\end{array}$ \\
\hline Helicopter & 128 & 20 & $15.63 \%$ \\
\hline Fighter & 68 & 10 & $14.70 \%$ \\
\hline Transport & 25 & 02 & $08.00 \%$ \\
\hline Total & 221 & 32 & $14.48 \%$ \\
\hline
\end{tabular}

$X^{2}=0.984: d f=2: p=n s(>0.05)$

Table-II revealed that, in almost all frequencies, the mean hearing threshold of helicopter pilot population was higher than the mean hearing threshold of fighter and transport population This difference was not significantly different( $\left.\mathrm{x}^{2}=2.185: \mathrm{df}=1: \mathrm{p}>0.05\right)$. 
Table-II Frequency distribution of mean (SD) of hearing threshold as per aircraft type $(n=32)$

\begin{tabular}{|c|c|c|c|c|c|c|c|c|c|c|}
\hline \multirow{2}{*}{$\begin{array}{c}\text { Aircraft } \\
\text { Type }\end{array}$} & \multirow[t]{2}{*}{ Ear } & \multicolumn{9}{|c|}{ Frequency } \\
\hline & & $250 \mathrm{~Hz}$ & $\begin{array}{l}500 \\
\mathrm{~Hz}\end{array}$ & $\begin{array}{l}750 \\
\mathrm{~Hz}\end{array}$ & $\begin{array}{l}1000 \\
\mathrm{~Hz}\end{array}$ & $\begin{array}{l}2000 \\
\mathrm{~Hz}\end{array}$ & $\begin{array}{l}3000 \\
\mathrm{~Hz}\end{array}$ & $\begin{array}{l}4000 \\
\mathrm{~Hz}\end{array}$ & $\begin{array}{l}6000 \\
\mathrm{~Hz}\end{array}$ & $\begin{array}{l}8000 \\
\mathrm{~Hz}\end{array}$ \\
\hline \multirow[t]{2}{*}{$\begin{array}{l}\text { Fighter } \\
(n=10)\end{array}$} & Right & $\begin{array}{l}10.00 \\
(00)\end{array}$ & $\begin{array}{l}10.00 \\
(00)\end{array}$ & $\begin{array}{l}10.63 \\
(1.76)\end{array}$ & $\begin{array}{l}10.63 \\
(1.76)\end{array}$ & $\begin{array}{l}13.13 \\
(4.58)\end{array}$ & $\begin{array}{l}19.38 \\
(9.79) \\
\end{array}$ & $\begin{array}{l}29.75 \\
(20.48)\end{array}$ & $\begin{array}{l}26.88 \\
(14.07)\end{array}$ & $\begin{array}{l}26.88 \\
(24.04)\end{array}$ \\
\hline & Left & $\begin{array}{l}10.00 \\
(00) \\
\end{array}$ & $\begin{array}{l}10.00 \\
(00) \\
\end{array}$ & $\begin{array}{l}10.00 \\
(00) \\
\end{array}$ & $\begin{array}{l}10.00 \\
(00) \\
\end{array}$ & $\begin{array}{l}10.00 \\
(00) \\
\end{array}$ & $\begin{array}{l}16.25 \\
(6.94) \\
\end{array}$ & $\begin{array}{l}25.63 \\
(15.45) \\
\end{array}$ & \begin{tabular}{|l|}
25.63 \\
$(16.13)$ \\
\end{tabular} & $\begin{array}{l}25.00 \\
(19.64) \\
\end{array}$ \\
\hline \multirow{2}{*}{$\begin{array}{c}\text { Heli } \\
\text { copter } \\
(n=20)\end{array}$} & Right & $\begin{array}{l}10.91 \\
(1.97)\end{array}$ & $\begin{array}{l}11.59 \\
(4.45)\end{array}$ & $\begin{array}{l}13.18 \\
(8.67) \\
\end{array}$ & $\begin{array}{l}14.77 \\
(11.18)\end{array}$ & $\begin{array}{l}16.14 \\
(13.08)\end{array}$ & $\begin{array}{l}22.50 \\
(17.37)\end{array}$ & $\begin{array}{l}30.00 \\
(20.00)\end{array}$ & $\begin{array}{l}32.05 \\
(17.37)\end{array}$ & $\begin{array}{l}33.41 \\
(17.75)\end{array}$ \\
\hline & Left & $\begin{array}{l}10.45 \\
(1.47) \\
\end{array}$ & $\begin{array}{l}10.45 \\
(1.47) \\
\end{array}$ & $\begin{array}{l}11.59 \\
(2.84) \\
\end{array}$ & $\begin{array}{l}12.95 \\
(4.79) \\
\end{array}$ & $\begin{array}{l}15.00 \\
(7.56) \\
\end{array}$ & $\begin{array}{l}23.64 \\
(11.56) \\
\end{array}$ & $\begin{array}{l}30.91 \\
(19.92) \\
\end{array}$ & $\begin{array}{l}31.36 \\
(15.28) \\
\end{array}$ & $\begin{array}{l}32.27 \\
(17.30) \\
\end{array}$ \\
\hline \multirow[t]{2}{*}{$\begin{array}{c}\text { Transport } \\
(n=02)\end{array}$} & Right & $\begin{array}{l}12.50 \\
(3.53)\end{array}$ & $\begin{array}{l}12.50 \\
(3.53)\end{array}$ & $\begin{array}{l}12.50 \\
(3.53) \\
\end{array}$ & $\begin{array}{l}12.50 \\
(3.53) \\
\end{array}$ & $\begin{array}{l}15.00 \\
(7.07)\end{array}$ & $\begin{array}{l}15.00 \\
(00)\end{array}$ & $\begin{array}{l}17.50 \\
(3.53)\end{array}$ & $\begin{array}{l}22.5 \\
(10.61)\end{array}$ & $\begin{array}{l}27.50 \\
(17.68)\end{array}$ \\
\hline & Left & $\begin{array}{l}10.00 \\
(00) \\
\end{array}$ & $\begin{array}{l}10.00 \\
(00) \\
\end{array}$ & $\begin{array}{l}10.00 \\
(00) \\
\end{array}$ & $\begin{array}{l}10.00 \\
(00) \\
\end{array}$ & $\begin{array}{l}20.00 \\
(14.14) \\
\end{array}$ & $\begin{array}{l}20.00 \\
(7.07) \\
\end{array}$ & $\begin{array}{l}17.50 \\
(3.54) \\
\end{array}$ & $\begin{array}{l}20.00 \\
(7.07)\end{array}$ & $\begin{array}{l}22.5 \\
(7.68) \\
\end{array}$ \\
\hline
\end{tabular}

The Table-III showing the mean hearing threshold from $250 \mathrm{kHz}$ to $8000 \mathrm{kHz}$ in both ears for two age groups. There was a prevalence of $20.31 \%(n=13)$ abnormal hearing the age group of more than 40 years and prevalence of abnormal hearing of $12.10 \%(\mathrm{n}=19)$ was found in the age group of 40 or less. $0-20 \mathrm{~dB}$ hearing loss is considered as normal and $21-40 \mathrm{~dB}$ hearing loss is considered as mild to moderate hearing loss. In both the age groups the hearing threshold in low frequency is almost similar but at 4,6 and $8 \mathrm{khz}$ hearing loss is greater in old age group than young age group.

Table-III: Frequency Distribution of mean (SD) hearing threshold (dB) in different frequencies of both ears in two age groups. $(\mathrm{n}=32)$

\begin{tabular}{|c|c|c|c|c|c|c|c|c|c|c|}
\hline \multirow[t]{2}{*}{ Age } & \multirow[t]{2}{*}{ Ear } & \multicolumn{9}{|c|}{ Frequency } \\
\hline & & $250 \mathrm{~Hz}$ & $\begin{array}{l}500 \\
\mathrm{~Hz}\end{array}$ & $\begin{array}{l}750 \\
\mathrm{~Hz}\end{array}$ & $\begin{array}{l}1000 \\
\mathrm{~Hz}\end{array}$ & $\begin{array}{l}2000 \\
\mathrm{~Hz}\end{array}$ & $\begin{array}{l}3000 \\
\mathrm{~Hz}\end{array}$ & $\begin{array}{l}4000 \\
\mathrm{~Hz}\end{array}$ & $\begin{array}{l}6000 \\
\mathrm{~Hz}\end{array}$ & $\begin{array}{l}8000 \\
\mathrm{~Hz}\end{array}$ \\
\hline \multirow[t]{2}{*}{$\begin{array}{l}>40 \text { Years } \\
(n=13)\end{array}$} & Right & $\begin{array}{l}11.15 \\
(2.19)\end{array}$ & $\begin{array}{l}12.31 \\
(5.63)\end{array}$ & $\begin{array}{l}15.00 \\
(10.99 \\
)\end{array}$ & $\begin{array}{l}17.69 \\
(13.94)\end{array}$ & $\begin{array}{l}19.23 \\
(16.31)\end{array}$ & $\begin{array}{l}25.77 \\
(15.39)\end{array}$ & $\begin{array}{l}33.46 \\
(19.30)\end{array}$ & $\begin{array}{l}33.46 \\
(15.05)\end{array}$ & $\begin{array}{l}34.62 \\
(16.13)\end{array}$ \\
\hline & Left & $\begin{array}{l}10.38 \\
(1.39)\end{array}$ & $\begin{array}{l}10.38 \\
(1.39)\end{array}$ & $\begin{array}{l}11.92 \\
(3.25)\end{array}$ & $\begin{array}{l}14.23 \\
(5.34) \\
\end{array}$ & $\begin{array}{l}15.77 \\
(9.32)\end{array}$ & $\begin{array}{l}25.00 \\
(11.37)\end{array}$ & $\begin{array}{l}33.08 \\
(18.55)\end{array}$ & $\begin{array}{l}29.62 \\
(11.63)\end{array}$ & $\begin{array}{l}27.69 \\
(13.17)\end{array}$ \\
\hline \multirow{2}{*}{$\begin{array}{l}\leq 40 \\
\text { Years } \\
(n=19)\end{array}$} & Right & $\begin{array}{l}10.53 \\
(1.58) \\
\end{array}$ & $\begin{array}{l}10.53 \\
(1.58) \\
\end{array}$ & $\begin{array}{l}10.79 \\
(1.88) \\
\end{array}$ & $\begin{array}{l}10.79 \\
(1.88) \\
\end{array}$ & $\begin{array}{l}12.63 \\
(4.21) \\
\end{array}$ & $\begin{array}{l}18.16 \\
(9.75)\end{array}$ & $\begin{array}{l}25.79 \\
(19.31)\end{array}$ & $\begin{array}{l}27.89 \\
(18.73)\end{array}$ & $\begin{array}{l}29.21 \\
(20.97)\end{array}$ \\
\hline & Left & $\begin{array}{l}10.26 \\
(1.15)\end{array}$ & $\begin{array}{l}10.26 \\
(1.15\end{array}$ & $\begin{array}{l}10.53 \\
(1.58)\end{array}$ & $\begin{array}{l}10.53 \\
(2.29)\end{array}$ & $\begin{array}{l}12.89 \\
(5.35) \\
\end{array}$ & $\begin{array}{l}19.21 \\
(9.76)\end{array}$ & $\begin{array}{l}25.79 \\
(18.13)\end{array}$ & $\begin{array}{l}28.95 \\
(17.53)\end{array}$ & $\begin{array}{l}31.31 \\
(20.47)\end{array}$ \\
\hline
\end{tabular}

The mean hearing threshold of 33.46 at $4 \mathrm{k}$ indicates mild to moderate hearing loss where as the high SD indicates that there was a wide individual susceptibility. The table also revealed that the mean hearing threshold is considerably higher in almost all frequencies in older age group than the young age group. In older age group, among the positive cases, $53.85 \%(\mathrm{n}=07)$ have moderate to severe hearing loss of 40 or more $\mathrm{dB}$, mostly on right ear whereas in younger age group $63.16 \%(n=12)$ have moderate to severe hearing loss among the positive cases and in majority of the cases right ear was affected. 
Mean hearing threshold of both ears of two age groups are shown in Fig-1

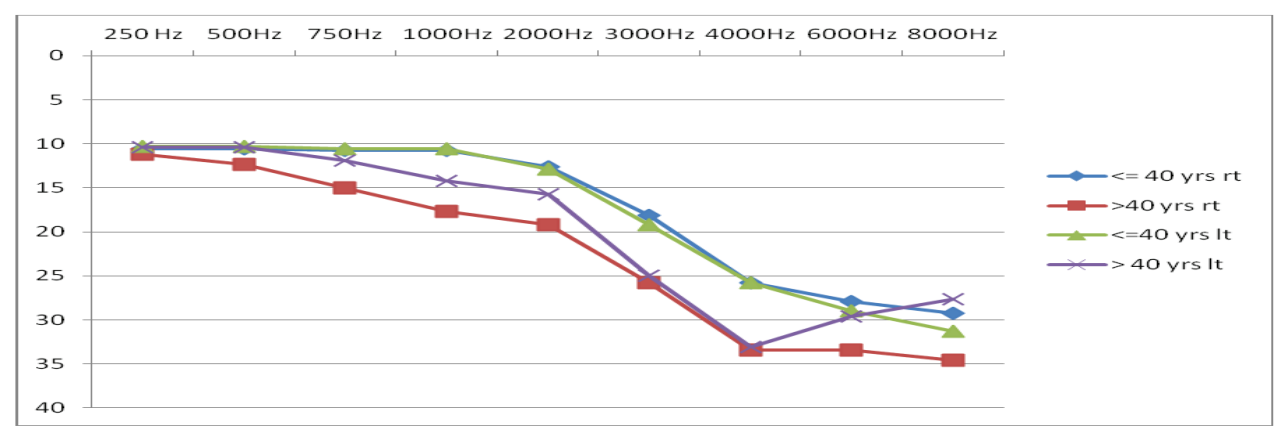

Fig-1: Mean hearing threshold of both ears of two age groups.

Table-IV shows that the hearing threshold is higher in almost all frequencies among the population having 1000 or more flying hours in comparison to those having less than 1000 flying hours. The hearing threshold difference found in this study is not statistically significant $(\mathrm{p}>0.05)$

Table-IV: Frequency Distribution of subject by mean (SD) hearing threshold (dB) in different frequencies and flying hours. $(\mathrm{n}=32)$

\begin{tabular}{|c|c|c|c|c|c|c|c|c|c|c|}
\hline \multirow{2}{*}{$\begin{array}{l}\text { Total } \\
\text { flying } \\
\text { hours }\end{array}$} & \multirow[t]{2}{*}{ Ear } & \multicolumn{9}{|c|}{ Frequency } \\
\hline & & $\begin{array}{l}250 \\
\mathrm{kHz}\end{array}$ & $\begin{array}{l}500 \\
\mathrm{kHz}\end{array}$ & $\begin{array}{l}750 \\
\mathrm{kHz}\end{array}$ & $\begin{array}{l}1000 \\
\mathrm{kHz}\end{array}$ & $\begin{array}{l}2000 \\
\mathrm{kHz}\end{array}$ & $\begin{array}{l}3000 \\
\mathrm{kHz}\end{array}$ & $\begin{array}{l}4000 \\
\mathrm{k} \mathrm{Hz}\end{array}$ & $\begin{array}{l}600 \\
\mathrm{k} \mathrm{Hz}\end{array}$ & $8000 \mathrm{kHz}$ \\
\hline \multirow{2}{*}{$\begin{array}{l}<1000 \\
\text { hrs } \\
(n=10)\end{array}$} & Right & $\begin{array}{l}11.00 \\
(2.11)\end{array}$ & $\begin{array}{l}11.00 \\
(2.11)\end{array}$ & $\begin{array}{l}10.5 \\
(1.58)\end{array}$ & $\begin{array}{l}10.5 \\
(1.58)\end{array}$ & $\begin{array}{l}13.00 \\
(4.8)\end{array}$ & $\begin{array}{l}19.5 \\
(11.89)\end{array}$ & $\begin{array}{l}28.00 \\
(22.01)\end{array}$ & $\begin{array}{l}26.50 \\
(28.28)\end{array}$ & $\begin{array}{l}25.00 \\
(20.41)\end{array}$ \\
\hline & Left & $\begin{array}{l}10.50 \\
(1.58)\end{array}$ & $\begin{array}{l}10.50 \\
(1.58)\end{array}$ & $\begin{array}{l}10.50 \\
(1.58)\end{array}$ & $\begin{array}{l}10.00 \\
(00)\end{array}$ & $\begin{array}{l}14.00 \\
(6.58)\end{array}$ & $\begin{array}{l}21.50 \\
(11.79)\end{array}$ & $\begin{array}{l}27.50 \\
(21.25)\end{array}$ & $\begin{array}{l}26.50 \\
(17.96)\end{array}$ & $\begin{array}{l}25.50 \\
(17.87)\end{array}$ \\
\hline \multirow[t]{2}{*}{$\begin{array}{l}\geq 1000 \\
\text { hrs } \\
(n=22)\end{array}$} & Right & $\begin{array}{l}10.68 \\
(1.76)\end{array}$ & $\begin{array}{l}11.36 \\
(4.41)\end{array}$ & $\begin{array}{l}13.41 \\
(8.65)\end{array}$ & $\begin{array}{l}15.00 \\
(11.13 \\
)\end{array}$ & $\begin{array}{l}16.36 \\
(13.0 \\
2)\end{array}$ & $\begin{array}{l}22.05 \\
(13.24)\end{array}$ & $\begin{array}{l}29.32 \\
(18.6)\end{array}$ & $\begin{array}{l}31.82 \\
(16.00)\end{array}$ & $\begin{array}{l}34.32 \\
(18.15)\end{array}$ \\
\hline & Left & $\begin{array}{l}10.23 \\
(1.06)\end{array}$ & $\begin{array}{l}10.23 \\
(1.06)\end{array}$ & $\begin{array}{l}11.36 \\
(2.75)\end{array}$ & $\begin{array}{l}12.95 \\
(4.79)\end{array}$ & $\begin{array}{l}14.09 \\
(7.66)\end{array}$ & $\begin{array}{l}21.59 \\
(10.39)\end{array}$ & $\begin{array}{l}29.32 \\
(17.41)\end{array}$ & $\begin{array}{l}30.44 \\
(14.05)\end{array}$ & $\begin{array}{l}31.82 \\
(17.69)\end{array}$ \\
\hline
\end{tabular}

Mean hearing threshold of both ears of two flying hours groups are shown in Fig-2

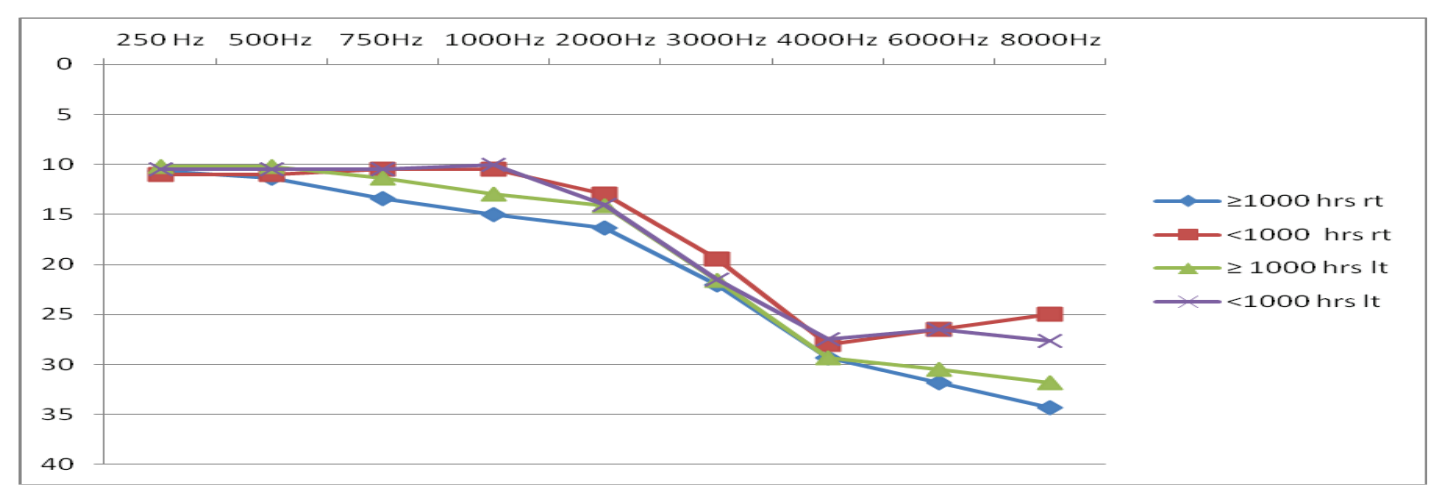

Fig-2: Mean hearing threshold of both ears of two flying hour groups 
Table-V shows that there is higher hearing threshold in almost all frequencies in right ear than the left ear. Those who have moderate to severe hearing loss of more than $40 \mathrm{~dB}$ or affected in the right ear in majority of cases. In this study inter aural hearing threshold difference is not statistically significant $(\mathrm{p}>0.05)$

Table-V: The frequency distribution of subject by average (mean $\pm \mathrm{SD}$ ) threshold HL $(\mathrm{dB})$ in both ears

\begin{tabular}{|l|l|l|l|l|l|l|l|l|l|}
\hline Frequency & $\begin{array}{l}550 \\
\mathrm{kHz}\end{array}$ & $\begin{array}{l}500 \\
\mathrm{kHz}\end{array}$ & $\begin{array}{l}750 \\
\mathrm{kHz}\end{array}$ & $\begin{array}{l}1000 \\
\mathrm{kHz}\end{array}$ & $\begin{array}{l}2000 \\
\mathrm{kHz}\end{array}$ & $\begin{array}{l}3000 \\
\mathrm{kHz}\end{array}$ & $\begin{array}{l}4000 \\
\mathrm{kHz}\end{array}$ & $\begin{array}{l}6000 \\
\mathrm{k} \mathrm{Hz}\end{array}$ & $\begin{array}{l}8000 \\
\mathrm{k} \mathrm{Hz}\end{array}$ \\
\hline Right ear & 10.78 & 11.25 & 12.50 & 30.59 & 15.31 & 21.25 & 28.91 & 30.16 & 31.41 \\
& $(1.85)$ & $(3.81)$ & $(7.29)$ & $(9.44)$ & $(11.14)$ & $(12.70)$ & $(19.27)$ & $(17.29$ & $(19.06)$ \\
\hline Left ear & 10.31 & 10.31 & 11.09 & 12.03 & 14.06 & 21.56 & 28.75 & 19.22 & 29.84 \\
& $(1.23)$ & $(1.23)$ & $(2.45)$ & $(4.19)$ & $(7.23)$ & $(10.66)$ & $(18.36)$ & $(15.19)$ & $(17.71)$ \\
\hline
\end{tabular}

Risk factors survey by the questionnaires analysis revealed that $34.4 \%$ of positive cases had history of leisure noise exposure, $3.1 \%$ had history of acoustic trauma, $6.3 \%$ had child hood otitis media, $6.3 \%$ had history of barotraumas, $3.1 \%$ had history of head injury, $3.1 \%$ had history of ototoxic medication, $12.5 \%$ have/had history of motor cycling, 3.1\% had history of car racing and $25 \%$ had history of shooting. It also revealed that all fighter pilots used helmet with air muff and Active Noise Reduction (ANR) but helicopter and transport pilot used helmet with air muff only as noise attenuation devise.

NIHL causes bilateral and progressive hearing loss. In aviation industries the sources of noise are transmission system, propeller, jet flux, cabin conditioning and cabin pressurization system, hydraulic system, communication equipments, sonic booms and armament discharge. In NIHL, typically the hearing thresholds dip at $4 \mathrm{kHz}$ (acoustic notch) $)^{1,3}$ showing in fig-3 below.

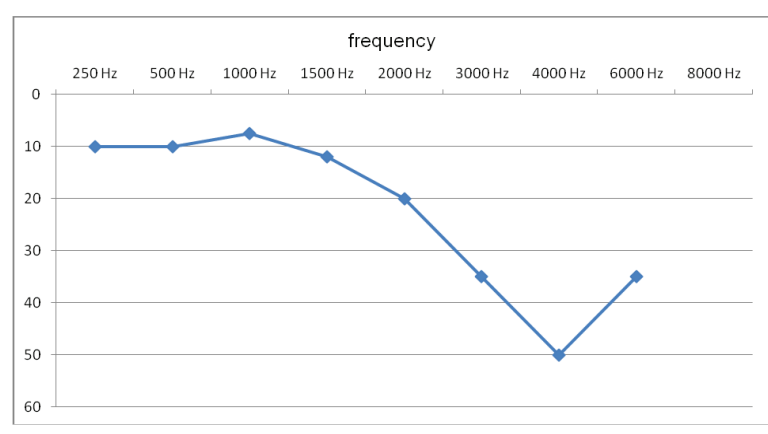

Fig-3: Typical hearing threshold with dip in $4 \mathrm{kHz}$ (acoustic notch) of NIHL.

\section{Discussion}

This study was conducted to find out the prevalence of noise induced hearing loss among the different aircrew population. All aircrew while being recruited in air force had hearing loss of less than $20 \mathrm{~dB}$ at any frequencies. ${ }^{5}$. Over the time, some of them developed hearing loss. The hazardous noisy work environment might be a major risk factor for hearing impairment. Noise may cause shift of hearing threshold temporarily or permanently ${ }^{1,6,7}$. Noise causes damage to the hair cells in basal turn of cochlea at $4 \mathrm{khz}$ sensitive area initially but if the noise exposure continues then it may spread to other frequencies ${ }^{\mathbf{1 , 3 , 4}}$. Whereas other confounding factors like age, leisure noise exposure, acoustic trauma, ototoxic medication, head injury and barotraumas may be contributing factors. In this study the mean hearing threshold of positive cases is skewed distributed in high frequency values like $4 \mathrm{k}$ and $6 \mathrm{k}$ that is the most susceptible frequency for noise induced hearing loss.

In this study on pilot population, $14.48 \%$ developed hearing loss and $85.52 \%$ had normal hearing. The hearing loss is mild to severe and at high frequencies. Among the different air crew population, the helicopter pilots are mostly affected than fighter and transport pilots. Similar type of study by Raynal M, Kossowski M and Job A on French military pilot had found that $29 \%$ of the pilot population had hearing loss and the most affected group was helicopter pilot which is consistent with our study. 
Among the positive cases, the right ear is affected in majority of cases than the left ear. Study by Raynal M, Kossowski M and Job a on French military pilot found that left ear had poorer performance than right ear at high frequencies. Our study is not consistent with this study. This dissimilarity is beyond the limit of our study.

Older pilots (more than 40 years) and those who had flying hours of more than 1000 hours have greater hearing loss in high frequencies $(4 \mathrm{kHz}$ and $6 \mathrm{kHz}$ ). This study result is consistent with similar type of study by Abel S M.

A good percentage of cases had history of leisure noise exposure that might have synergistic effect with aircraft noise. In this study there is no significant mean difference between the leisure noise exposure and non exposure group.

\section{Conclusion}

Noise induced hearing loss is a fairly common phenomenon in aviation industry. NIHL usually occurs at high frequencies especially at $4000 \mathrm{~Hz}$. For military aviators, in addition to aircraft noise other occupational and environmental noise might be the contributing factors. In our study, $14.48 \%$ aircrew population developed hearing loss and helicopter pilot's population was mostly affected. Pilots of more than 40 years of age and those with more than 1000 flying hours had mean hearing threshold worse than other group. As noise exposure to aircrew is inevitable so hearing loss prevention strategies might play a pivotal role to save aircrew hearing. Active surveillance of hearing protection practices might have beneficiary effect. Steps can be taken for early detection of NIHL and hearing conservation program.

\section{References}

1. John Ernsting, Anthony N, Nicholson and David j. Rain ford, Aviation Medicine, 3rd ed, Great Britain, Butterworth Heinemann, 1999, p.323-4.

2. Daniel T, Fitzpatrick. An Analysis of Noise-induced Hearing Loss in Army Helicopter Pilots, Aviation, Space and Environmental Medicine 1988; 10:937-41.

3. David j, Rainford and David P. Gradwell, Ernsting's Aviation Medicine, 4th ed, London, Hodder Arnold, 2006; p.720-2, 411-2.

4. Sharon M, Abel. Hearing loss in Military Aviation and Other Trades: Investigation of Prevalence and Risk Factors, Aviation, Space and Environmental Medicine 2005; 76: 1128-35.

5. Raynal M, Kossowski M, and Job A. Hearing in Military Pilots: One-Time Audiomerty in Pilots of Fighters, Transports and Helicopters, Aviation, Space, and Environmental Medicine 2006; 77:57-61.

6. Qiang Y, George W, Rebok, Susan P. Baker, and Guohua Li.Hearing Deficit in a Birth Cohort of U.S Male Commuter Air Carrier and Air Taxi Pilots. Aviation, Space, and Environmental Medicine 2008; 79:1051-5.

7. Laukli E, Ylikuski J. Noise-induced Hearing Impairment and Noise Protection. Oulu, Finland: University of Oulu; 2004: 63-6. 